\title{
CROWN RUST ON PERENNIAL RYEGRASS IN FIELD TRIALS
}

\author{
H.S. Easton' ${ }^{1}$, B.M. Cooper ${ }^{2}$, T.J. Fraser ${ }^{3}$ and KH. Widdup ${ }^{4}$ \\ Grasslands Division, DSIR \\ 'Palmerston North, ${ }^{2}$ Kaikohe, ${ }^{3}$ Lincoln, ${ }^{4}$ Gore
}

\begin{abstract}
Crown rustinfection of 11 perennial ryegrass cultivars varied significantly and consistently Over 6 sites. 'Grasslands Ariki,' the new cultivar 'Yatsyn' and Grasslands selections G26 and G33 were less infected than 'Grasslands Nui', 'Elett' or 'Grasslands Ruanui'. 'Droughtmaster' and 'Marathon' proved more susceptible than most
\end{abstract}

Keywords: Crown rust, Puccinia coronata, perennial ryegrass

\section{INTRODUCTION}

Crown rust (Puccinia coronata) is a common pathogen of perennial ryegrass (Lolium perenne) in New Zealand (Lancashire \& Latch 1966) and elsewhere, particularly in late summer when temperature and humidity are high. It reduces the photosynthetic area and renders the foliage unpalatable to livestock.

The number of perennial ryegrass cultivars offered to farmers has expanded in recent years, and susceptibility to crown rust is an important element in assessing their value.

Data from field trials at several locations for cultivars currently available, and some soon to be present in the market, are presented below.

\section{METHODS}

As part of a breeding programme, perennial ryegrass lines were sown in 1987 in $1 \mathrm{~m}$ rows, $30 \mathrm{~cm}$ apart, at 6 locations: Kaikohe, Wairakei, Palmerston North, Aorangi research area west of Palmerston North (all autumn sown), Lincoln and Gore (spring sown). Current and prospective cultivars were included as controls. Rows are grazed by sheep when necessary.

At each site, crown rust infection was noted in late summer and autumn of 1988 , on a scale of 0 (clean) to 5 (severe infection). Stem rust ( $P$. graminis) infection and other leaf lesions may have confounded the notes a little, but the major effect was crown rust. Data for the control cultivars were analysed for each site, and overall. Cultivar mean notes were calculated by weighting for the inverse square root of site error mean square.

\section{RESULTS}

Infection occurred on all cultivars at all sites. Cultivars differed significantly at all sites except Kaikohe (data not shown), where all were noted as severly infected. Significant statistical interaction between cultivar and site did not hide consistent trends in cultivar performance (Table 1).

G28 and G33 (Grasslands selections under trial), 'Yatsyn' and 'Grasslands Ariki were consistently less infected than 'Grasslands Nui', 'Ellett' or 'Grasslands Ruanui'. 
Table 1. Cultivar mean crown rust scores for 5 sites, weighted by inverse site error mean square.

\begin{tabular}{llll}
\hline Yatsyn & 3.75 & G33 & 3.80 \\
G28 & 4.14 & Ariki & 4.16 \\
Ellett & 4.52 & Takapau Persistor & 4.61 \\
Nui & 4.71 & Ruanui & 4.91 \\
Marathon & 5.15 & Droughtmaster & 5.41 \\
Victorian & 6.71 & I.s d. (5\%) & 0.83 \\
\hline
\end{tabular}

'Droughtmaster' was severely infected at all sites, as were 'Marathon' and two high endophyte lines derived from Ruanui. The Australian cultivar 'Victorian' was always very severely infected.

\section{DISCUSSION}

None of the cultivars available in new Zealand is immune to crown rust, but some are consistently less infected than others. Conditions in summer 1987-88 were conducive to crown rust infection, which was heavy even in drier regions such as Canterbury.

That the most recent cultivars are the least infected (with the exceptions of 'Marathon' and 'Droughtmaster') indicates the effectiveness of controlled selection.

The consistent superiority of 'Takapau Persistor' to 'Droughtmaster', both from Hawke's Bay, results from selection specifically for this character (MAF, cultivar descriptions). The similarity of these to Ruanui and its derivatives, in reaction to rust and in other respects (unpublished data), suggests that they are derived from the same Hawke's Bay material studied by Levy in the 1920s, leading to his release of the elite strain later designated 'Grasslands Ruanui' (Easton 1983; Burgess 1987; Hunt \& Easton 1989).

The poor performance of 'Marathon' may reflect its being bred principally in Canterbury, where crown rust is usually less severe than stem rust. 'Marathon' is reported to be less affected by stem rust than Nui or 'Ellett' (A.V. Stewart, pers comm).

There is clearly potential for further improvement in perennial ryegrass for resistance to crown rust. However, farmers can use cultivars which are less susceptible than some alternatives.

Acknowledgements

We thank Mr R. Hunter and other staff of the Wairakei Research Station, MAFtech, for use of land and surveillance of the Wairakei site; and Miss E. Cornege and Mr D.L. Ryan, Grasslands Division, for assistance with the trials at Palmerston North, Aorangi and Gore.

\section{References}

Burgess R.E. (1987) Proceedmgs NZ Grassland Association 48: 69-92.

Easton H.S. (1983). Ryegrass In Wratt G.S. \& Smith H.C. (Eds) Plant breeding in New Zealand. DSIR, pp. 229-

Hunt W.F., Easton H.S. (1989). Fifty years of ryegrass research in New Zealand. Proceedmgs NZ Grassland Association 50:

Lancashire J.A.. Latch G.C.M. (1966). NZ journal of agricultural research 9' 628-40. 